\title{
Kandidaatin tutkielma muutoksessa
}

SANNA-MARI AHONEN, SATU ELO, MARI KANGASNIEMI, EEVA LIIKANEN \& KATI UTRIAINEN

\begin{abstract}
Kirjoittajat kuvaavat kandidaatin tutkielman vaiheittaista toteutumista aikuisopiskelijoiden monitieteisenä yhteistyönä Oulun yliopistossa. Teoreettisesti toteutustavan uudistaminen nojautui prosessikirjoittamiseen ja henkilökohtaisen ryhmäohjauksen mahdollisuuksiin opiskelijan oppimisen tukemisessa ja ohjauksen kehittämisessä.
\end{abstract}

$\mathrm{O}$ ulun yliopiston lääketieteellisen tiedekunnan terveystieteiden laitoksella on viisi terveystieteiden maisterin tutkintoon johtavaa koulutusohjelmaa ${ }^{1}$. Näitä ovat hoitotiede, kliininen laboratoriotiede, radiografia, terveyshallintotiede ja terveystieteiden opettajan koulutusohjelma. Vuosittainen sisäänotto on yhteensä 45 opiskelijaa. Opiskelijat ovat aikuisopiskelijoita, joilla on jo jokin sosiaalija terveydenhuollon opisto- tai ammattikorkeakoulututkinto (mm. sairaanhoitajan, bioanalyytikon, terveydenhoitajan, fysioterapeutin). Koulutus antaa valmiudet erilaisiin terveydenhuollon kliinisiin asiantuntijatehtäviin, sosiaali- ja terveydenhuollon hallinnon ja talouden asiantuntija-, suunnittelu- ja johtamistehtäviin sekä terveysalan tutkimus- ja opetustyöhön.

Terveystieteiden koulutus kuuluu uuden tutkintorakenteen mukaisiin tutkintoihin. Rakenneuudistuksen taustalla on niin kutsuttu Bolognan prosessi, jonka avulla eurooppalaista korkeakoulutusta on pyritty kehittämään yhteismitallisemmaksi ja kilpailukykyisemmäksi. Tavoitteena on ollut luoda Eurooppaan yhtenäinen korkeakoulutusalue vuoteen 2010 mennessä.

Eurooppalaista tutkintorakennetta on kehitetty pääsääntöisesti ns. kahden (kolmen) syklin mallissa. Ensimmäisen syklin muodostaa 3-4-vuotinen kandidaattitason tutkinto ja toisen maisteritason tutkinto (sekä kolmannen syklin akateemiset jatkotutkinnot). Alemman korkeakoulututkinnon eli kandidaatin tutkinnon opintojen laajuus on terveystieteissä 180 opintopistettä (op) ja ylem- män tutkinnon eli maisterin tutkinnon laajuus 120 op. Pääsääntöisesti opiskelijat suorittavat sekä alemman että ylemmän korkeakoulututkinnon. (Asetus 794/2004, Tutkinnonuudistus Suomessa.) Asetuksen (794/2004) mukaan alempaan korkeakoulututkintoon sisältyy 6-10 opintopisteen laajuinen opinnäytetyö eli kandidaatin tutkielma sekä kirjallinen kypsyyskoe, jolla opiskelija osoittaa perehtyneisyytensä opinnäytteen alaan ja suomen tai ruotsin kielen taitoon. Kandidaatin tutkielman tarkoituksena on perehtyä tieteelliseen toimintaan ja laatia kirjallisuuden ja/tai empiirisen aineiston pohjalta tieteellisiä periaatteita noudattava kirjallinen tutkielma.

Tutkintojen rakenteellisen kehittämisen lisäksi tutkinnonuudistuksen tavoitteena on ollut myös tutkintojen sisällöllinen uudistaminen. Oulun ylipiston terveystieteiden laitoksen kandidaatin tutkielman (10 op) perustan muodostaa aiempaan tutkintorakenteeseen kuulunut proseminaari (3 opintoviikkoa). Se koostui aloitusseminaarista, itsenäisestä työskentelystä, yksilöohjauksesta ja valmiiden tutkielmien seminaariesittelyistä. Jokainen pääaine toteutti ja järjesti omat seminaarinsa.

Merkittävinä epäkohtina koettiin kuitenkin epätarkoituksenmukainen pääaineittainen eriytyminen, opiskelijoiden yksinäiseksi koettu itsenäinen työskentely sekä seminaarien vuorovaikutuksettomuus. Näiden palautteiden vuoksi uuden tutkintorakenteen myötä opintojakson toteuttamista päätettiin uudistaa. Kaikkien viiden koulutusohjelman opiskelijat haluttiin monitieteellisyyden tu- 
kemiseksi samaan oppikurssiin. Opintojen monitieteellisyys vastaisi terveydenhuollon käytännön moninäkökulmaista todellisuutta. Tämän artikkelin tarkoituksena on kuvata vuoden 2007 kandidaatin tutkielman vaiheittaista toteutusta Oulun yliopiston terveystieteiden laitoksella, arvioida toteutunutta opintojaksoa opiskelija- ja opettajapalautteen perusteella sekä edelleen kehittää sitä.

\section{Opintojakson rakentuminen ja lähtökohdat}

Uuden kandidaatin tutkielma -opintojakson viisihenkinen suunnittelu- ja toteutustyöryhmä koostui kutakin pääainetta edustavasta opettajasta. Uudistuksen lähtökohtana olivat aikaisemmilta vuosilta saatu palaute sekä teoreettisina lähtökohtina prosessikirjoittamisen (Björk \& Räisänen 1996) ja opiskelijoiden ohjauksen hyödyllisyys (Ansela, Haapaniemi \& Pirttimäki 2005) oppimisen tukena. Aikaisempina vuosina saadun palautteen perusteella eri pääaineiden seminaarit päätettiin yhdistää ja tehdä opintojaksosta nelivaiheinen. Opintojaksolle osallistui yhteensä 49 kolmannen lukukauden opiskelijaa. Ensimmäinen vaihe oli opiskelijoiden orientointi, toinen tutkielmien työstäminen ohjauksessa, kolmas kandidaattikonferenssi ja neljäs kirjallinen kypsyyskoe. Opintojakson ensimmäinen vaihe alkoi informaatioluennoilla. Luennolla opiskelijoille kerrottiin opintojakson tavoitteet ja rakenne sekä ohjattiin pienryhmätyöskentelyyn. Opintojakson tavoitteena oli, että opiskelija perehtyy tieteellisen tutkimuksen tekemiseen ja laatii kirjallisen ja/tai empiirisen aineiston pohjalta tieteellisiä periaatteita noudattavan kirjallisen tutkielman (Opinto-opas 2007-2008). Opiskelijoiden ensimmäinen tehtävä oli laatia yhden arkin pituinen ideapaperi tutkielman aiheesta ja palauttaa se kahden viikon kuluessa opintojaksosta vastaavalle oman pääaineensa opettajalle. Opiskelijoiden valitsemat tutkielmien aiheet nousivat sekä tieteellisistä että käytännöllisistä kysymyksistä ja olivat tyypillisesti viitekehystä tulevaa pro gradu -tutkielmaa varten.

\section{Prosessikirjoittaminen ja henkilökohtainen ryhmäohjaus}

Opintojakson toinen vaihe oli kandidaatin tutkielmien työstäminen ohjauksessa. Kun opiskelijat olivat palauttaneet ideapaperinsa, ohjaavat opet- tajat jaottelivat opiskelijat monitieteellisiin pienryhmiin. Ryhmien kooksi määritettiin kolmesta neljään henkeä, koska tämän kokoisena pienryhmä toimii opiskelumuotona parhaiten (Lindholm-Ylänne ym. 2003). Jaottelussa ryhmien määrittymisen perusteena ei siis ollut pääaine, vaan pienryhmät muodostettiin joko opiskelijoiden valitsemien aiheiden tai lähestymistapojen perusteella.

Pienryhmät ohjeistettiin kokoontumaan syksyn aikana vähintään neljä kertaa, joista kahteen heillä oli mahdollisuus kutsua ohjaava opettaja. Pienryhmien kokoontumiselle laadittiin prosessikirjoittamisen ja henkilökohtaisen ryhmäohjauksen kirjallisuuden perusteella tukirunko teemoista, joita opiskelijat saattoivat hyödyntää tapaamisissaan. Ensimmäisen tapaamisen teemoina olivat ryhmäytyminen, tapaamisajoista sopiminen, lähdekritiikki, aiheen rajaus, prosessikirjoittamisen lähtökohdat sekä kirjallisen työn ohjeet. Toisen tapaamisen teemoina olivat tieteellinen kirjoittaminen, kirjallisen työn rakenne ja töiden arviointi- ja palautekeskustelu, ja kolmannen analyysi ja synteesi sekä pohdinta ja sen merkitys. Neljännellä tapaamisella perehdyttiin suulliseen ja postieriesitykseen, otsikon ja tekstin väliseen suhteeseen ja töiden arviointi- ja palautekeskusteluun. Tapaamisiin, joissa ohjaava opettaja oli läsnä, opiskelijoiden tuli toimittaa opettajalle etukäteen sen hetkiset ongelma- tai pohdintakohdat. Näitä opiskelijoiden henkilökohtaisia kysymyksiä käsiteltiin yhteisissä tapaamisissa opettajan kanssa.

Pienryhmätyöskentelyn lähtökohtana oli toimia opiskelijan oppimisen tukena, tukea prosessikirjoittamiseen ja kehittää ohjausta. Oppimisen tukeminen pienryhmässä perustuu vuorovaikutukseen ja vertaisarviointiin. Vuorovaikutuksessa voidaan luoda hyväksyvä ja oppimista tukeva ilmapiiri, joka tarjoaa opiskelijalle mahdollisuuden interaktiiviseen oppimiseen, sosiaaliseen tukeen ja kontaktien luomiseen. Turvallinen ympäristö mahdollistaa ryhmän jäsenten uskaltautumisen omien työprosessien tutkimiseen ja uusien työtapojen kokeiluun (Nummenmaa \& Lautamatti 2004). Tämän myötä myös oman oppimisen reflektio muuttuu avoimemmaksi (Nummenmaa \& Lautamatti 2004, Hätönen \& Romppanen 2006). Vertaisryhmä auttaa yksilöitymään, sillä ryhmässä jokainen voi tiedostaa omat yksilölliset tavat toimia ja kuulla muiden toimintatavoista. (Nummenmaa \& Lautamatti 2004.) Siten opiskelija saa sekä itse tukea toisilta että voi samalla olla avuksi toisten oppimisessa (Matikainen \& Puro 1997). Pienryhmätyöskente- 
lyssä tapahtuu myös jatkuvaa vertaisarviointia eli tasavertaisena koetun kumppanin, kuten opiskelutoverin, arviointia toisen toiminnasta (Hätönen \& Romppanen 2006). Vertaisarviota tukee myös opettajan pienryhmälle samanaikaisesti antama palaute, koska opiskelijoilla on usein kirjoituksissaan samoja ongelmakohtia (Lindholm-Ylänne \& Wager 2003).

Toinen pienryhmätyöskentelyä ohjaava lähtökohta oli prosessikirjoittaminen, jota pidetään tehokkaimpana kirjoittamisen opettamisen ja oppimisen muotona (Björk \& Räisänen 1996). Kirjoitusprosessin onnistuminen edellyttää kuitenkin opiskelijalta itsesäätelytaitoja. Näillä tarkoitetaan opiskelijan kykyä ottaa vastuu omasta oppimisestaan, kykyä asettaa ja seurata tavoitteiden saavuttamista sekä kykyä ylläpitää motivaatiota. Kun kirjoitusprosessia aikataulutetaan, se etenee paremmin. (Lindholm-Ylänne \& Wager 2003.) Prosessikirjoittaminen toteutettiin ja sitä tuettiin säännöllisten tapaamisten, ryhmäohjausten sekä saadun ja annetun palautteen kautta.

Kolmas opintojakson uudistamisen merkittävä lähtökohta oli ohjauksen kehittäminen. Opiskelijan ohjauksen kehittäminen on jatkuva prosessi. Ohjausta voidaan pitää laadukkaana, mikäli se auttaa opiskelijaa oppimaan helpommin, nopeammin ja syvällisemmin kuin ilman ohjausta olisi ollut mahdollista (Ansela ym. 2005).

Opintojakson ohjauksen muodoksi valittiin ryhmäohjaus. Ryhmäohjauksella tarkoitetaan pienryhmissä tapahtuvaa opiskelijakeskeistä ohjausta (Nummenmaa \& Lautamatti 2004), jossa oppimista ohjataan oppimistehtävillä (Ruponen ym. 2000) ja sekä opiskelija että opettaja ovat aktiivisessa roolissa. Ryhmäohjaus aktivoi ja tukee opiskelijan oppimista. Perinteinen seminaaritoiminta on hyvin ohjaajakeskeistä ja ryhmän aktivoinnista huolimatta opiskelijoiden osallistuminen jää usein vähäiseksi. Ryhmäohjaus kytkeytyy reflektiiviseen ohjausnäkemykseen, jolloin ohjauksen kohteena ovat ennen kaikkea prosessit. Opiskelijalla on aktiivinen rooli ja ohjauksen tavoitteena on saada opiskelija pohtimaan, tiedostamaan ja jäsentämään omaan oppimiseensa liittyviä kysymyksiä. Ohjaajan rooli on kanssakulkija ja kumppani, joka auttaa löytämään uusia polkuja ja näkemään uusia maisemia sekä järjestelemään hajallaan olevia ajatuksia. Ohjaustapahtumaa kuvaa opiskelijan itseohjautuvuus ja ohjaajan rooli on enemmän kysymyksiä herättävä kuin vastauksia antava. Ryhmäohjauksen on todettu tukevan oppimista, vaikka erita- soisten opinnäytetöiden ohjauksessa ryhmän ja yhteisöllisen kumppanuuden mahdollisuuksia on kuitenkin hyödynnetty varsin vähän (Nummenmaa \& Lautamatti 2004).

Ohjaus haastaa myös ohjaavan opettajan ohjaus- ja toimintataidot ja kehittää ohjaajia monipuolisesti (Nummenmaa \& Lautamatti 2004). Ryhmäohjauksessa ohjaaja on perinteisen autoritäärisen opastajan sijaan suunnannäyttäjä, oppimisen varmistaja, vuorovaikutuksen taitaja, työskentelyn ylläpitäjä ja alan asiantuntija (Kyngäs ym. 2007). Opettajan tulisi tuntea opetussuunnitelman kokonaisuus, hänellä tulisi olla sosiaalisia neuvottelutaitoja, kyky ohjata oppimisprosessia, toimia tiimin jäsenenä (Ansela ym 2005), esittää olennaisia kysymyksiä, tuoda esiin ja tukea opiskelijoiden vahvuuksia sekä asettaa tavoitteita (Matikainen \& Puro 1997, Ruponen ym. 2000). Lisäksi ohjaajalta edellytetään ohjattavan aiheen sisällöllistä tuntemusta. (Ansela ym. 2005.) Koska ryhmäohjauksessa voidaan käsitellä useamman opiskelijan töissä ilmeneviä rakenteellisia tai muodollisia ongelmia yhtäaikaisesti, ohjaajalta vapautuu voimavaroja tieteellisen ohjauksen syventämiseen (Nummenmaa \& Lautamatti 2004). Ryhmäohjaus on myös taloudellista, koska ohjausta voidaan antaa suuremmalle joukolle samalla kertaa (Nummenmaa \& Lautamatti 2004, Kyngäs ym. 2007).

\section{Kandidaattikonferenssi ja kypsyyskoe}

Opintojakson kolmas vaihe oli niin kutsuttu kandidaattikonferenssi. Konferenssi kesti päivän ja se järjestettiin tiedekunnan tiloissa. Päivän tarkoituksena oli tarjota opiskelijoille kokemus tieteellisestä konferenssista ja siihen valmistautumisesta. Päivä koostui 49 esityksestä, joista 14 oli suullisia ja 35 posteria. Opiskelijoiden tuli valita pienryhmästään yksi, joka esittää työnsä suullisesti ja ryhmän muut jäsenet laativat työstään posterin. Lisäksi opiskelijat äänestivät mielestään parhaan suullisen ja posteriesityksen. Lähes kaikkien opiskelijoiden tutkielmien pohjana oli kirjallisuus, koska moni opiskelija perehtyi jo tässä vaiheessa tulevan pro gradu -tutkielman aiheeseen.

Neljäs vaihe oli kandidaatintutkielmaan sisältyvä kirjallinen kypsyyskoe, joka suoritettiin konferenssipäivän jälkeen. Siinä opiskelijat osoittivat tenttiolosuhteissa hallitsevansa käsittelemänsä tutkielman aiheen kielellisesti ja sisällöllisesti. 


\section{Opintojakson toteutumisen arviointi}

Opintojakson yhteydessä opiskelijoilta kerättiin kirjallinen palaute. Palautelomake jaettiin konferenssimateriaalin (ohjelma, suullisten ja posteri esitysten tiedot, äänestysliput) yhteydessä. Lomakkeessa oli viisi kysymystä. Ensimmäisessä kysymyksessä pyydettiin palautetta opintojakson järjestäytymisestä (info, ryhmäjako, ajoitus), toisessa ryhmien sisäisestä toiminnasta (tapaamiset, osallistuminen, vertaisohjaus, yksilö/ryhmäohjauksen tarve), kolmannessa ohjaavan opettajan työskentelystä (tapaamiset, ohjaus) ja neljännessä kandidaattikonferenssista (valmistelu, ohjelma, suulliset esitykset ja posterit). Viides kysymys oli avoin, jossa opiskelijoita pyydettiin kommentoimaan mahdollisesti muita teemoja. Koska opiskelijoiden kirjoittamat viidennen kysymyksen sisällöt käsittelivät 1-4 kysymysten teemoja, ne käsitellään osana näitä kohtia. Vastauksia palautettiin yhteensä 41. Vastausprosentti oli 84 prosenttia.

Järjestäytyminen. Opiskelijoiden mukaan opintojaksosta saatu sekä ennakko- että jakson aikana annettu informaatio oli riittävää ja se annettiin ajoissa. Se oli hyvää, selkeää ja sujuvaa. Lisää informaatiota toivottiin postereiden tekemisestä ja niiden käytännön toteutuksesta (painatus, hinnoittelu). Suurin osa opiskelijoista koki, että ryhmäjako oli onnistunut ja tuki heidän oppimistaan.

Ryhmien sisäinen toiminta. Opiskelijat kokivat, että ryhmätyöskentely oli mielekästä ja oppimista edistävää. He kuvasivat pienryhmien toimintaa ennemmin vertaistukena kuin vertaisohjauksena. Valtaosa ryhmistä tapasi kaikki neljä kertaa ja moni ryhmä jopa kuusi kertaa. Opiskelijat kokivat sitoutumisen ryhmään toimivakasi ja tärkeäksi. Ryhmän toiminta oli kannustavaa, joustavaa, monipuolista ja kriittistä. Parasta heidän mukaansa oli, että ryhmässä työskenneltäessä muilta sai tukea ja neuvoa. Ryhmien toimivuutta edisti myös se, jos aiheet tukivat toisiaan. Merkittävä toimintaa tukeva tekijä oli myös se, että ryhmä sai sopia keskenään tapaamisaikansa. Opiskelijoiden mukaan toisten töihin perehtyminen oli tärkeä edellytys tapaamisten onnistumiselle.

Ryhmätyöskentelyn dynamiikkaan hajottavana tekijänä koettiin se, että kaikki eivät tukeneet toisia, osa opiskelijoista vetäytyi ryhmästä ja ilmaantui vain muutamille tapaamisille. Opiskelijoiden toisilleen antama palaute saattoi olla viitteellistä ja ylimalkaista, eivätkä kaikki olleet perehtyneet riittävästi toisten töihin. Keskustelu oli kyllä ollut mukavaa, mutta ei antanut tukea töiden etenemiseen. Opiskelijoiden mukaan ryhmätyöskentely voisi toimia tehokkaammin, jos palaute annettaisiin pareittain tai jokaiselle määrättäisiin oma opponentti. Myös vertaistuelle annetun selkeämmän etukäteisohjeistuksen ajateltiin parantavan ryhmän toimintaa.

Ohjaavan opettajan kanssa työskentely. Opiskelijoiden mukaan opettajalta saatu ohjaus oli opiskelijalähtöistä, kiitettävää ja riittävää. He kuvasivat ohjausta kannustavaksi, hedelmälliseksi, rakentavaksi, päteväksi ja ammattitaitoiseksi. Opettajilta toivottiin yhtenäistä ohjaustyyliä. Osa opiskelijoista toivoi saavansa opettajalta valmiita ratkaisuja ja korjausehdotuksia esittämiinsä ongelmakohtiin. Suurin osa opiskelijoista oli kuitenkin tyytyväinen, että opettaja esitti asioista selkeitä ja moninäkökulmaisia kommentteja, mutta opiskelija itse sai ja joutui kuitenkin miettimään valintansa ja niiden perustelut.

Opiskelijat kaipasivat ohjaajaa useammin pienryhmätapaamisiin. Lisäksi he toivoivat henkilökohtaista yksilöohjausta. Opiskelijat olisivat kaivanneet ohjausta reaaliajassa eli nopeammin omien eikä ryhmän ohjauksellisten tarpeiden ja aikataulujen mukaan.

Kandidaattikonferenssi. Opiskelijoiden mielestä järjestetty kandidaattikonferenssi oli yksimielisesti hyvä, tarpeellinen, opettavainen ja onnistunut kokonaisuus. Tosin postereiden koettiin jäävän liian vähälle huomiolle. Opiskelijoiden mukaan päivä oli kattava ja monitieteinen läpileikkaus laitoksen opiskelijoiden tutkielma-aiheisiin. Konferenssi koettiin hyvänä harjoituksena tulevaisuutta varten ja se madalsi kynnystä osallistua oikeisiin tieteellisiin konferensseihin.

Opiskelijat toivoivat saavansa lopullisesta tutkielmasta henkilökohtaisen kirjallisen palautteen. Päivän informaatio oli toiminut hyvin, mutta opiskelijat toivoivat lisää tukea ja opetusta suullisen ja posteriesityksen rakentamiseen ja toteuttamiseen.

\section{Johtopäätökset ja pohdinta}

Opintojakson toteuttaminen herätti pohtiman kysymyksiä opetuksen kehittämisestä, monitieteellisyyden, prosessikirjoittamisen ja ryhmäohjauksen merkityksestä sekä käytännön järjestelyistä. Lisäksi keskeiseksi kysymykseksi nousi yliopisto-opettajien vertaistuki ja yhteistyö. Opetuksen kehittäminen on osa opettajan työn mielekkyyttä. Hänellä on akateeminen vapaus kehittää omaa opetus- 
taan sisällöllisesti ja työtavoilta entistä paremmin opiskelijaa hyödyntäväksi (Karjalainen 2003). Opetuksen kehittämisessä palautteen merkitys sekä kehittämisen jatkuvuus ovat erittäin tärkeitä. Kehittämisessä on olennaista tuoda esille myös mahdollisten muutosten taustalla olevat perusteet. Siten opetuksen pedagogisten lähtökohtien tunnistaminen ja kehittäminen ovat perusta, jonka varaan opetus voidaan tietoisesti rakentaa. Tämän opintojakson pedagogisiksi teoreettisiksi perustoiksi määritettiin prosessikirjoittaminen (Björk \& Räisänen 1996, Lindholm-Ylänne ym. 2003, Nummenmaa \& Lautamatti 2004) ja pienryhmäohjaus (Ruponen ym. 2000, Nummenmaa \& Lautamatti 2004) opiskelijan oppimisen tukemiseksi. Nämä perusteet ohjasivat opintojaksossa sekä sen rakenteellisia lähtökohtia että sen toteuttamista. Opiskelijat kokivat näiden avulla oppimisen mielekkääksi ja hyödylliseksi. Jatkossa olisikin syytä yhä paremmin avata niiden merkitystä ja teoreettista taustaa myös opiskelijoille.

Toinen keskeinen kysymys opintojakson toteuttamisessa oli monitieteellisyys. Sekä opiskelijat että opettajat kokivat, että laitoksen usean eri pääaineen yhteinen opintojakso oli rikastuttava ja hedelmällinen. Koska sekä tiedeyhteisö että käytännön toiminta ovat kuitenkin monitieteellisiä toimintaympäristöjä, tulisi jo koulutuksen aikana saada valmiuksia ja mahdollisuus kasvaa ja kehittää ajattelua monitieteellisessä tarkastelussa.

Kolmanneksi pohdintaa herätti prosessikirjoittaminen. Sen oppiminen on erityisen tärkeää, koska tieteellinen kirjoittaminen on tyypillisesti luonteeltaan prosessikirjoittamista. Opiskelijoille ei ollut opintojakson alkuvaiheessa helppoa antaa omia keskeneräisiä töitään opettajalle tai ryhmän jäsenille luettaviksi, mutta he kuitenkin kypsyivät opintojakson aikana sekä ottamaan vastaan että antamaan palautetta teksteistään. Lopulta opiskelijat kokivat prosessikirjoittamisen olevan erittäin hedelmällistä ja eteenpäin vievää.

Ryhmäohjaus on varsin vähän hyödynnetty ohjaustapa. Tämän opintojakson kokemuksen perusteella sitä voidaan kuitenkin pitää toimivana ja aikaa säästävänä menetelmänä, jolla päästään hyviin lopputuloksiin. Opiskelijat olivat aktiivisia ja innostuneita, ja ryhmässä tapahtuva vertailu motivoi heitä pysymään aikataulussa ja kiinnittämään huomiota oman työn laatuun. Ryhmäohjaus tuki opiskelijoiden itsenäisyyttä ja itseohjautuvuutta. He kokivat mielekkäänä sen, että valmiiden neuvojen sijaan opiskelijoille ohjattiin ainoastaan vä- lineitä pohtia kysymyksiä, mutta he itse prosessoivat valintansa ja ratkaisunsa. Toisten opiskelijoiden ja opettajan kanssa käydyt keskustelut ovat tärkeä osa tieteelliseen keskusteluun kasvamista. Kandidaatin tutkielman tekemistä motivoi myös tuleva pro gradu -tutkielma, joka miellettiin luontevaksi jatkoksi kandidaatin tutkielmalle. Jotta ryhmäohjaus olisi mielekästä, opiskelijoita tulisi pystyä entistä paremmin sitouttamaan toimintaan ja näkemään vastuunsa myös toisten oppimisesta. Tämä on myös kysymys, joka tulisi avata jo informaatioluennoilla.

Ryhmäohjaus perustui opiskelijoiden henkilökohtaisille ongelmakohdille omassa kandidaatin tutkielmassaan, ja näitä tarkasteltiin ryhmässä. Henkilökohtaisen eli yksilöllisen ohjauksen määrää ei liene mielekästä lisätä, mutta ryhmäohjauksessa tapahtuvan henkilökohtaisen ohjauksen roolia on syytä tuoda aiempaa kirkkaammin esille. Siten henkilökohtainen ohjaus ja yksilöohjaus eivät ole synonyymejä. On syytä kiinnittää huomio myös siihen, että opiskelijoiden ongelmakohdat eivät ole toisistaan paljon poikkeavia vaan varsin samanlaisia. Vaikka ohjaus toteutetaan ryhmäohjauksena, ohjaava opettaja paneutuu jokaisen opiskelijan tutkielmaan henkilökohtaisesti ja antaa siitä henkilökohtaisen palautteen ja arvioinnin. Opiskelijat toivoivat yhdenmukaisuutta opettajien ohjauskäytöntöihin. Opettajalla tulee kuitenkin olla vapaus toimia oman tyylinsä mukaisesti.

Ryhmäohjaus on haastava ohjaustapa myös opettajalle. Opiskelijat haluavat paljon opettajan tukea, mutta ryhmäohjausta käytettäessä opettaja pystyy keskittymään tutkielmien tieteelliseen ohjaukseen, ydinasioihin ja tieteelliseen kirjoittamiseen. Ryhmäohjaus on askel kohti opiskelijakeskeisempää toimintatapaa, jossa opettaja on ohjaaja ja keskustelun suuntaaja. Hän pystyy keskustelussa hyödyntämään ryhmässä esiin nousseita moniulotteisia kysymyksiä. Kokonaisuudessaan ryhmäohjaus on innovatiivinen, raikas ja intensiivinen ohjaustapa, jossa opettajan ohjaus koetaan erittäin tärkeänä siitä huolimatta, että opiskelijat toimivat itseohjautuvasti. Ryhmäohjaus saattoi vaikuttaa myös tuloksellisuuteen eli kaikki opiskelijat saivat kandidaatin tutkielmansa valmiiksi määräajassa.

Kandidaatin tutkielman julkinen esittäminen Kandidaattikonferenssissa motivoi opiskelijoita tuottamaan mahdollisimman laadukkaan työn. Kandidaattikonferenssiin kulminoituivat monet keskeiset tieteellisen toiminnan kysymykset ja tie- 
dekäytännöt. Julkinen oman tutkielman esitteleminen myös madalsi kynnystä osallistua seuraaviin tieteellisiin konferensseihin. Kandidaattikonferenssista saatu palaute oli kokonaisuudessaan erittäin hyvä.

Opettajat kokivat erityisen positiivisena yhdessä toteutetun opintojakson tarjoaman vertaistuen. Sitä oli mahdollista saada opintojakson kaikissa vaiheissa suunnittelussa, toteutuksessa ja arvioinnissa. Opettajat pystyivät perustelemaan ratkaisunsa yhteisesti sovittujen periaatteiden ja rakenteiden perusteella. Myös opiskelijan tasa-arvoista kohtelua ja arviointia voitiin lisätä. Opinnäytetöiden välisiä eroja voitiin myös kaventaa. Opettajan rooli on yliopistossa varsin yksinäinen, koska se on eriytyneisiin asiantuntijuuksiin perustuvaa. Aikuiskasvatuksen kentässä yliopistoopetus on siinä mielessä erityistä, että opettajat toimivat yksin. Opintojaksojen ja opettamisen kehittämisen kannalta olisi kuitenkin ensiarvoisen tärkeää toimia yhteistyössä. Se auttaa tunnistamaan sekä omia että myös toisten toimintatapoja ja siten myös muuttamaan käytänteitä.

Kokemus opettajien monitieteisestä vertaistuesta herätti ajatuksen toimintakulttuurin muutoksen tarpeesta eli yliopisto-opettajien yhteistyömahdollisuuksien lisäämisestä. Yliopisto-opettajan työ on yksinäistä, mikä saattaa osittain juontaa opetukseen kiinteästi liittyvästä tutkimustehtävästä: kukin opettaja opettaa omaa tutkimusaluettaan, jolloin keskinäinen yhteistyö ja laajempien näkökulmien avaaminen jää helposti vähäiselle huomiolle. Yliopisto-opettajalla ei välttämättä ole kokonaisvastuuta ja -kuvaa laitoksen opinnoista kokonaisuutena. Kokemukset yhteisistä opintojaksoista avaavat uusia näkökulmia ja mahdollisuuksia sekä opetukseen että tieteelliseen tutkimukseen.

\section{Viite}

1. Nämä tutkinnot voi suorittaa terveystieteiden laitoksella. Lisäksi tiedekunnassa voi suorittaa terveystieteiden maisterin tutkinnon hyvinvointitekniikan koulutusohjelmassa.

\section{Lähteet}

Ansela, M., Haapaniemi, T. \& Pirttimäki, S. (2005). Yliopisto-opiskelijan hops. Ohjaajan opas. Kuopion yliopisto.

Björk, L. \& Räisänen, C. (1996). Academic writing. A university course. Lund. Studentlitteratus.

Hätönen, H. \& Romppanen, B. (2006). Arviointi ja palaute oppimisen ja kehityksen tukena. Educa-Instituutti Oy.

Karjalainen, A. (toim.) (2003). Akateeminen opetussuunnitelmatyö. Oulun yliopisto. Opetuksen kehittämisyksikkö.

Kyngäs H., Kääriäinen, M., Poskiparta, M., Johansson, K., Hirvonen, E. \& Renfors, T. (2007). Ohjaaminen hoitotyössä. WSOY.

Lindholm-Ylänne, S. Repo-Kaarento, S. \& Nevgi A. (2003). Massa- ja ryhmäopetuksen haasteet. Teoksessa Lindholm-Ylänne, S. \& Nevgi, A. (toim.) Yliopisto- ja korkeakouluopettajan käsikirja. WSOY.

Lindholm-Ylänne, S. \& Wager, M. (2003). Tieteellisten opinnäytetöiden ohjaaminen. Teoksessa Lindholm-Ylänne, S. \& Nevgi, A. (toim.) Yliopisto- ja korkeakouluopettajan käsikirja. WSOY.

Matikainen, J. \& Puro, U. (1997). Tutor oppivan ryhmän tukena. Aikuiskasvatus, 17(4), 307312.

Nummenmaa, A. \& Lautamatti L. (2004). Ohjaajana opinnäytetöiden työprosesseissa. Ryhmäohjauksen käytäntöä ja teoriaa. Tampere University Press.

Opinto-opas (2007-2008). Lääketieteellinen tiedekunta. Oulun yliopisto.

Ruponen R., Nummenmaa, A.R. \& Koivuluhta, M. (2000) Ryhmäohjaus muutoksen mahdollisuuden maisemana. Teoksessa Onnismaa, J., Pasanen, H. \& Spangar, T. (toim.) Ohjaus ammattina ja tieteenalana - ohjauksen lähestymistavat ja ohjaustutkimus. PS-Kustannus. 